\title{
EVOLUTION OF THE EASTERN PARTNERSHIP REGARDING ASSOCIATED COUNTRIES
}

\section{ЕВОЛЮЦІЯ СХІДНОГО АСОЦІЙОВАНИХ КРАЇН}

\section{ЭВОЛЮЦИЯ ВОСТОЧНОГО АССОЦИИРОВАННЫХ СТРАН

\author{
ПАРТНЕРСТВА
} \\ В ОТНОШЕНИИ}

\section{Berezovska I.}

Candidate of Legal Sciences, Senior Research Associate of the research department of the Institute of International Relations of Taras Shevchenko National University of Kyiv. Berezovska.iir@gmail.com

\section{Березовська I. A.}

Кандидат юридичних наук, старший науковий співробітник науково-дослідної частини Інституту міжнародних відносин Київського національного університету імені Тараса Шевченка. Berezovska.iir@gmail.com

\section{Березовская И. А}

Кандидат юридических наук, старший научный сотрудник научно-исследовательской части Института международных отношений Киевского национального университета имени Тараса Шевченко. Berezovska.iir@gmail.com

\begin{abstract}
The entry into force of the Association Agreements concluded by the European Union with Georgia, Moldova and Ukraine has become a key moment in the Eastern Partnership evolution resulting in the widened gap between the partnership countries. The article emphasizes that these agreements created the legal basis for enhancing the EU law impact on the associated countries resulting in the Europeanisation of the legislation of the latter. It notes that due to implementation of these agreements the associated countries have already started large-scale internal reforms.

The article shows that against the apparent success in the implementation by the EaP associated countries there emerge initiatives to implement a separate advanced format of EU cooperation with the associated countries - the Eastern Partnership Plus.

The completion in 2020 of the implementation period of the Eastern Partnership's main working document 20 Priorities for 2020 together with the perspective of holding of the next sixth summit of all partnership countries give a chance to renew the partnership based on the more for more principle and to develop new mechanisms of work that can meet the associated countries' intentions to deepen the EU integration.

The article points out that the announcement by the European Union of broad strategic consultations on the updates of the Eastern Partnership is a positive element that should be used by the associated countries to convince the EU of the need for a new strategy that will complement the Eastern Partnership and make it more focused on the integration objectives of the three countries.

It gives arguments that Association Agreements updating efforts may be an efficient way to make such aspirations come true, analyses the grounds and directions for such update.

The article underlines that the associated countries need to use the time remaining to deciding on the further evolution of the EaP for the definite implementation of the current operation programme and demonstration of significant progress in the Association Agreements implementation.
\end{abstract}

Keywords: Eastern Partnership, European Union, Association Agreement, EaP Associated Countries, Free Trade Area, legislation approximation. 
Анотація. Ключовим моментом еволючії Східного Партнерства, внаслідок якого посилилась диференціація між країнами-учасницями стало набрання чинності угодами про асоиіацію, укладеними Свросоюзом з Грузією, Молдовою та Україною. Підкреслено, щзо иі угоди створили правові засади для посилення впливу права ЄС на асоційовані краӥни, внаслідок чого здійснюється європеїзачія законодавства останніх. Відзначено, щчо $в$ результаті виконання зазначених угод, асочійовані країни вже розпочали масштабні внутрішні реформи.

Продемонстровано, щуо на тлі очевидних успіхів у реалізаџії асоџійованими країнами Східного Партнерства з'являються ініціативи щзодо впровадження в його рамках окремого просунутого формату співробітництва Свросоюзу з асочійованими крайнами - Східне Партнерство-плюс.

Завершення в 2020 рочі часу імплементачії основного наразі робочого документу Східного Партнерства "20 пріоритетів до 2020 року» разом з перспективою проведення чергового шостого саміту усіх країн-учасниць дають шанс на оновлення партнерства на основі принцииу диференціації «більше за більше» та вироблення нових механізмів роботи, здатних задовольнити наміри асочійованих країн поглиблювати інтеграцію з СС.

B статті відзначається, щуо оголошення Свросоюзом широких стратегічних консультацій щзодо оновлення Східного Партнерства є позитивним моментом, який має бути використаний асоиійованими краӥнами для переконання $\epsilon C$ в необхідності запровадження нової стратегії для асочійованих партнерів, щุо доповнить Східне Партнерство і зробить його більш сфокусованим на інтеграчійних иілях для трьох краӥн.

Доводиться, що ефективним засобом реалізації таких прагнень, може стати робота щцодо оновлення угод про асоціацію, аналізуються підстави та напрямки такого оновлення.

Підкреслюсться необхідність використання асоиійованими країнами часу, щяо залишається до прийняття рішення про подальшу еволюцію Східного Партнерства, для остаточного виконання чинної робочої програми та демонстрації вагомого прогресу в імплементації угод про асоиіацію.

Ключові слова: Східне партнерство, Свропейський союз, угода про асоціацію, асочійовані краӥни СхП, зона вільної торгівлі, наближення законодавства.

Аннотация. Ключевым моментом эволючии Восточного партнерства, в результате которого усилилась дифференцииаия между странами-участницами стало вступление в силу соглашений об ассочиачии, заключенных Евросоюзом с Грузией, Молдовой и Украиной. Подчеркнуто, что эти соглашения создали правовые основы для усиления воздействия права EC на ассочиированные страны, в результате чего осуществляется европеизация законодательства последних. Отмечено, что в результате выполнения указанных соглашений ассочиированные страны уже начали масштабные внутренние реформьл.

Продемонстрировано, что на фоне очевидных успехов в реализации ассоџиированными странами Восточного партнерства появляются инициативы по внедрению в его рамках отдельного продвинутого формата сотрудничества Евросоюза с ассоциированными странами - Восточное Партнерство-плюс.

B статье отмечается, что начало Евросоюзом иироких стратегических консультащий по обновлению Восточного партнерства является положстельным моментом, который должен быть использован ассоциированными странами для убеждения EC в необходимости введения новой стратегии для ассоциированных партнеров, которая бы дополнила Восточное партнерство и сделала его более сфокусированным на интеграчионных иелях трех стран.

Подчеркивается необходимость использования ассочиированными странами времени, остающегося до принятия решения о дальнейшей эволючии Восточного партнерства, для окончательного выполнения действующей рабочей программы и демонстрации весомого прогресса в имплементации соглашений об ассочиащии. 
Ключевые слова: Восточное партнерство, Европейский союз, соглашение об ассоциации, ассочичрованные страны ВП, зона свободной торговли, сближение законодательства.

Definition of Issue. It makes 10 years in 2019 since the European Union launched the Eastern Partnership (EaP) policy. A 10-year period makes a line to reflect on the success and, at the same time, to review the development perspectives of this policy. Over this period, the geopolitical and security realia of international relations have changed dramatically, the internal political situation in the EU and partnership countries have transformed significantly. The new reality of international relations in the region, including the Russia's aggression effects, pushed the EU to the need to update the EaP. The European Union has already started structural consultations about the future of the Eastern Partnership. This is a chance for Ukraine to develop a new format of the Eastern Partnership that would take into account the association relations outcomes and make a basis for boosting of the integration of the Eastern Partnership associated countries with the EU. Given the new internal political reality of Ukraine and the institutional updates in the European Union, the study of EaP evolution trends becomes particularly topical.

Review of Latest Studies and Publications. The details of the Eastern Partnership policy implementation are actively studied by the European and Ukrainian researcher societies. Certain regulations of the Eastern Partnership initiative have become a subject of discussions by the partnership countries as well as scientists, political analysts and independent experts. Among the studies of the first outcomes of the partnership in certain sectors, it is worth mentioning the works by Barbe, Costa, Lavenex, Lehmkuhl, Natorski, Surralles, Youngs, Whichmann. Relation of EaP to the Association Agreements conclusion is analysed in the works by Ch. Hillion, A. Mayhew, and the special study by a group of European scientists led by N. Šišková From Eastern Partnership to the Association. A Legal and Political Analysis is of particular note.

In the Ukrainian realm, the general issues of the EaP implementation and outcomes of ordinary partnership summits are traditionally analysed by political theorists and international relations experts, e.g.: V. Kopiyka, V. Mandzhola, O.Shnyrkov, T. Shynkarenko, N. Vesela etc. For the studies of the legal aspects of EaP, one will mention the works of T. Anakina, Z. Makarukha, R. Petrov, K. Smyrnova, I. Yakovyuk. It is worth noting individually the Expert Evaluation of the joint working document Eastern Partnership - 20 Deliverables for 2020: Focusing on Key Priorities and Tangible Results; the evaluation was performed by experts of the Ukrainian National Platform of the Eastern Partnership Civil Society Forum with the support of the Civic Synergy Project [17].

While the studies dedicated to the EaP evolution perspectives have emerged only this EaP anniversary year. In this respect, we can mention the works by experts V. Martyniuk, I. Nahorniak, S. Sydorenko.

Objective of Article. The objective of this work is to analyse the legal basis for the Eastern Partnership evolution in the context of strengthening of cooperation between the European Union and Eastern European Partners.

Presentation of Basic Material of the Study. As it is known, the Eastern Partnership (EaP) initiative, that was for the first time presented in Prague on May 07, 2009, is the policy of the European Union aimed at strengthening relations with the six eastern post-Soviet countries of the Eastern Europe and the South Caucasus (Azerbaijan, Belarus, Armenia, Georgia, Moldova and Ukraine) and a continuation of the EU-initiated European Neighbourhood Policy. The introduction of the Eastern Partnership has made a clear distinction between the mentioned European countries and other neighbours of the European Union from North Africa and the Middle East that even in terms of a formal geographic criterion do not have perspectives of the EU membership. However, this initiative covers post-Soviet countries that have different approaches and goals in the development of the relations with the EU. On the one hand, it has spread to Azerbaijan and Belarus, the countries with authoritarian government, far from close integration with the European Union, Armenia with unstable pro-European orientation, and, on the other hand, to pro-European-oriented Georgia and Moldova as well as to Ukraine whose strategic interest is to have a clear perspective of EU-membership. 
This is the reason why the EaP has been criticized inside the partnership countries since the very beginning. Against the undeniable possible attitude to the Eastern Partnership initiative related to the creation of special programme for the Eastern Europe countries, the mentioned policy is treated as too general and overall. As for certain countries, like Ukraine, Moldova, Georgia, it offered too little (as it was not about the EU membership), while for others - Belarus, Armenia, Azerbaijan - too much (the EU integration).

The differences in the relations with different partnership countries become particularly scorching against the establishment of their EU association.

The Ukraine's strong endeavour to strengthen the EU integration by concluding the Association Agreement caused the extension of the Association relations to other Eastern Partnership members. This was first reflected in the European Commission's Communication on the Eastern Partnership dated December 3, 2008, stating "Association Agreements can provide a response to partners' aspirations for a closer relationship. This contractual frame for a stronger engagement, superseding the current Partnership and Cooperation Agreements, will be negotiated with partners that are willing and able to take on the resulting far-reaching commitments with the EU. These new agreements will create a strong political bond and promote further convergence by establishing a closer link to EU legislation and standards. They should also advance cooperation on Common Foreign and Security Policy and European Security and Defence Policy" [1].

Therefore, the conclusion of Association Agreements with each of the partnership countries including the creation of Free Trade Areas (FTA) became from the very beginning the Eastern Partnership basis that should have been accompanied with visa liberalization, cooperation for energy security and special funding of the project by the EU.

In 2012-2013, there were completed AA negotiations with four Eastern Partnership countries: Armenia, Georgia, Moldova and Ukraine. Adopted in September 2013 the decision on Armenia's accession to the Customs Union of Russia, Belarus and Kazakhstan meant that the AA and FTA were no longer an option for Armenia. The dramatic story of the EU-Ukraine AA entry into force after the President Yanukovych's refusal to sign it at the EaP Vilnius Summit on November 28-29, 2013 (including the Revolution of Dignity, Russia's opposition and the Dutch referendum) finally ended on September 1, 2017, when according to the decision of the EU Council 2017/1248 dated July 11, 2017 the AA with Ukraine finally came into force. Earlier, since July 1, 2016, the Association Agreements with Moldova and Georgia became effective bringing these three countries into a separate institutional group of the Eastern Partnership.

Association agreements concluded by the EU with the countries of the Eastern Partnership refer to the new generation of agreements [Loo, 2016: 434]. The Association Agreements concluded with Georgia, Moldova and Ukraine have the same structure and are very close in terms of their content.

It should be noted that, in terms of the sectors of cooperation and the volume of commitments undertaken, the mentioned Agreements are the largest among international agreements concluded by Georgia, Moldova and Ukraine so far. Their entry into force opened a new stage in the development of relations between the EU and Eastern Partnership associated countries. Implementation of the AA has become a factor determining the further directions of the associated countries' legal framework development. First of all, this is about a significant increase in the EU law influence on the associated countries' legal systems, especially in the areas covered by the deep and comprehensive FTA where the AA engages to gradually approximate their legislation closer to the EU norms and standards. With the fulfilment of these commitments, the Georgia's, Moldova's and Ukraine's legislations get gradually Europeanized.

In accordance with the general commitment in all three AAs, the associated countries will "gradually approximate their legislation to the EU law" (Art. 417 of AA with Georgia, Art. 448 of AA with Moldova, and Art. 474 of AA with Ukraine). This provision is clearly reflected in the specific commitments and mechanisms defined both in the AA Titles of the FTA and in the annexes and protocols to the AA containing a large list of references to the secondary EU legislation, thus consolidating the most of norms of the EU acquis. Their general analysis shows that the legislation 
approximation caused by the FTA introduction becomes the main form of Europeanization of the associated countries' legislation.

The Agreements introduce various mechanisms of sectoral Europeanization, where the European Union is determined to share the part of its internal market with associated countries, subject to the approximation of their respective legislation. At the same time, in the various spheres of trade relations covered by the Agreement, the legislation harmonization provisions are set out differently: in some, the legislation approximation process is clearly linked to the entry of the relevant goods into the EU internal market, and therefore the annexes contain a detailed list of the relevant legal and regulatory framework of the EU, while others are more general or even do not provide a clear legal commitment to legislation approximation. To some extent, such a difference in the approach to harmonization is stipulated by the various objectives of each chapter of the AA Title of the FTA.

The scope of the planned reforms of legal regulation which will be carried out as a result of the fulfilment of AA commitments gives a basis to state the expected large-scale Europeanization of a number of the associated countries' legislative branches. Among the areas where innovative approaches to legal regulation and modernization of the sectoral legislation of the associated countries are based on the EU acquis, there are sectors: technical barriers to trade, sanitary and phytosanitary measures, establishment, trade in services and e-commerce, public procurement, competition etc.

It is worth mentioning that the Agreements provide for clear conditions for the practical implementation of the FTA and the liberalization of trade relations with the timelines, completeness and quality of the approximation of the legislation of the associated countries to the EU acquis, including the aspects of implementation and enforcement.

Thus, as a result of the establishment of the Association and FTA between the European Union and Eastern Partnership countries, a new stage of the Europeanization of the legislation of the associated countries aimed at ensuring their economic integration with the EU has been launched. The European Union is trying to spread its values, principles and legal norms, setting them as conditions that should be respected by the associated countries in accordance with the treaty obligations.

At the same time, it is obvious that the impact of European legislation on the associated countries' legislation due to the liberalization of access to the EU market will have global consequences not only for their trade relations with the EU but also will lead to global modernization of a significant number of social relations spheres within the associated countries. Due to the AA commitments, the Europeanization becomes a systemic legal phenomenon that ensures integration of Georgia, Moldova, and Ukraine with the EU internal market and determines the direction of development of the associated countries' legal systems.

Consequently, the conclusion and coming into force of the Association Agreements with the three partner countries became a landmark in the Eastern Partnership evolution causing the increase in the gap between the partner countries.

The associated countries have already launched the large-scale internal reforms conditioned by the AA. Whereas the other three partnership countries are not eager to join the European reforms, and Armenia and Belarus cannot do that even in theory, since they have to follow the criteria of the Eurasian Economic Union as its members.

So far, that most significant result of association is the trade intensification between the associated countries and EU. Even under the Russian military aggression and economic pressure, the export from Georgia, Moldova and Ukraine has grown over the last three years. Against the drastic reduction of the export from Russia, the EU FTA allowed the associated countries to minimize the effects of economic warfare initiated by the RF. For example, the trade has now become a true success story for Ukraine within the Eastern Partnership [15]. Experts estimate that moving away from GOST standards inherited from the Soviet Union and adopting current EU technical standards, adapting legislation to the EU acquis and eliminating non-tariff barriers have contributed to the economic growth of countries and created long-term perspectives for their 
modernization and sustainable development. Following the AA, the three EaP countries not only gain wider access to the 500-million EU single market but also integrate into the global supply chains [11].

Introduction of visa-free regimes with the three associated countries is another big success of the EaP, especially for ordinary citizens.

The ongoing format of multilateral cooperation between the EU and partners, remaining a platform for tries to establish regional cooperation is also on the list of EaP's successes. The establishment of the Georgia, Moldova and Ukraine Inter-Parliamentary Assembly and the Euronest Parliamentary Assembly (EU - Eastern Neighbours) should also be mentioned here.

Given these success stories resulting from the association implementation the obvious gap between the EaP countries has led to the idea of a new additional format of cooperation EU +3 . Looking at the trends in the past years, it seems the countries of the region can be divided into two groups. Moldova, Georgia, and Ukraine - which signed Association Agreements with the EU show higher standards of democracy than the other three countries: Armenia, Belarus, and Azerbaijan [7].

Before to the Brussels EaP Summit in November 2017, the European Parliament adopted a resolution with recommendations and offered its own vision of the future development of the EaP [2]. One of the main novelties of this document was the possibility of separating Ukraine, Georgia and Moldova from other partners in the 'Eastern Partnership Plus' format, the EU associated partners started lobbying it back in 2015.

A possibility of having access to the EU's customs, energy and digital unions as well as to join the Schengen area and abolish the mobile roaming rates was at the bottom. In addition, the resolution provides for the establishment of a trust fund for Ukraine, Georgia and Moldova, that can focus on private and public investments in social and economic infrastructure.

Unfortunately, this resolution has never been endorsed by the European Council, and it was hardly possible to have a joint final resolution at the Brussels Summit. The idea of Marshall's plan for Ukraine has not been implemented either.

The Eastern Partnership policy efficiency seems to wane in recent years. On the one hand, this is due to the internal political situation of the European Union. According to Artyomov, "the EU is more concerned about the post-Brexit life, the behaviour of Trump, the North Stream-2 and the establishment of a common security architecture with Russia rather than about the security of its Eastern flank and in the Eastern Partnership countries" [Artyomov 2019: 19]. On the other hand, it is caused by a factor that is regarded as a major failure of the EaP policy: its inability to ensure the stability and security in the region [13]. Although it was considered the EaP format priority, the security situation in the region in view of the war in Ukraine only aggravated, and potential mechanisms to strengthen the security support in the region by EU Member States have not been established yet.

The EU membership of the associated countries is equally problematic. One cannot disagree with Blockmans' view that "as long as there is no consensus within the EU on the ultimate goal of strengthening relations with neighbouring countries, it can be argued that the declared purpose of the Eastern Partnership - strengthening the stability of the institutions and societies of the six participating countries - has been put into the anabiotic state. The application of the Extension Lite methodology will soon reach its limit in the countries that are not offered the EU accession" [11]. Against the recent freezing of EU enlargement with the Balkan countries and the apparent fatigue of Europeans from the ambitious goals of the EaP associated countries, Ukraine in particular, the membership perspectives seem unrealistic in the medium term.

It is now clear that no major revision of the EaP should be expected by the end of 2020 . Therefore, the key task at the current stage of the EaP evolution is the partner countries to deliver the results set out in joint working document Eastern Partnership - 20 Deliverables for 2020: Focusing on Key Priorities and Tangible Results [3]. The document is a blueprint aimed at achieving the objectives in 2017-2020 in 20 sectors grouped into four key priority areas determined by the 2015 EaP Summit: 1. Economic Development and Market Opportunities; 2. Strengthening 
institutions and good governance; 3. connectivity, energy efficiency, environment and climate change; 4 . mobility and people-to-people contacts.

It should be noted that the Key Priorities 2020 intersect with the AA, and the tools suggested to implement them can be used in the Agreement implementation process [Makarukha 2019: 19]. Moreover, the document has a number of objectives that are additional to the AA, and therefore represent an "added value" for the associated countries. In particular, there are additional objectives across all cross-sectoral sections, with completely new tasks presented in the Strategic Communications, Pluralism and Independence of Media section. Particular attention should be paid to the sections that consist entirely of new objectives compared to the AA: gaps in access to finance and financial infrastructure; new job opportunities at local and regional levels; implementation of key judicial reforms; expansion of TEN-T main networks; European School of the Eastern Partnership. In addition, new objectives are in the sections on energy supply, energy efficiency, renewable energy use, greenhouse gas emissions, environment and adaptation to climate change, youth, education, skills development and culture; research and innovation [19].

The completion of its implementation in 2020 together with the perspective of holding the next sixth EaP Summit, that was not held in 2019 due to the uncertainty with the Brexit and the reelection of EU institutions, give a chance to update partnerships based on the more for more principle and to develop new mechanisms of work that can meet the intentions of the associated countries to deepen the EU integration. Most likely, the vision of the EaP's future will be presented during the term when Germany holds the presidency of the EU in the second half of the next year, and this is the time when the implementation of the Partnership's 20 for 2020 programme comes to end.

Searching for the means how to ensure that the Eastern Partnership remains relevant and inclusive the EU announced a broad and inclusive structured consultation process to reflect on the future strategic direction of the Eastern Partnership and a new - post 2020 - generation of deliverables. For this purpose, all stakeholders are invited to send their contributions on the future of the Eastern Partnership post-2020 policy framework using the EU Survey. The deadline for sending contributions is until 31 October 2019 [16].

Holding such consultations is undoubtedly a positive point. There are already first initiatives on the directions of the EaP evolution being articulated.

Thus, the Ukrainian party continues expressing its hope for a special partnership in the Eastern Partnership Plus format. At the heart of the Ukrainian party's proposals lies the concept of introducing a deeper differentiation, e.g. by setting new goals in the relations with the associated partners through integration into the EU's '4 Unions' (Customs, Energy, Digital and Schengen), a more active use of the EU Common Security and Defence Policy instruments, improving communication to overcome the Russian misinformation [Makarukha 2019: 18].

According to Dmytro Kuleba the Deputy Prime Minister for the European and Euro-Atlantic Integration, "a new EU strategy for the associated partners is needed, complementing the EaP and making it more focused on integration goals for the three countries. We will be grateful to the EU for recognizing that these three countries are different while maintaining relations with the other three (Armenia, Azerbaijan, Belarus)" [18].

In our opinion, the Association Agreements updating efforts may be an efficient way for making such aspirations come true. All three agreements, given the continuous development of EU law, provide for a possibility to update them. This may be done either to update the Annexes containing the list of EU acts the laws of the associated countries are to be harmonized to, and to move to further stages to deepen the integration, this is made possible as a result of fulfilment of their harmonization commitments.

Thus, in accordance with Article 463 of the AA with Ukraine, Article 406 of the AA with Georgia and Article 436 of the AA with Moldova, the competent Association Council may take decisions aimed at achieving the AA objectives. In particular, it may update or amend the annexes to the Agreement taking into account developments in the EU law and applicable standards set out in international instruments as deemed appropriate by the Parties. 
In addition, Article 481 of the AA with Ukraine (unlike similar provisions of the AAs with Georgia and Moldova) provides that the Parties shall review comprehensively the achievement of the objectives of this Agreement five years after its entry into force as well as at any other time by mutual agreement of the Parties.

One may now say that the AA update has already started. The first example of such update in Ukraine was the ratification by the Verkhovna Rada in June 2019 of the updated "Energy" Annex 27 to the AA providing for new energy standards and rules that will allow Ukraine to integrate into the EU's internal energy markets. [4].

"More ambitious tasks in trade liberalization" and the realization of the intention to transform the trade with the European Union into economic integration are among Ukraine's expectations of the new format.

Having considered this, another direction of the AA updating capable of deepening integration could be the conclusion of Agreements on Conformity Assessment and Acceptability of Industrial Products (ACAA) provided for by Art. 57 of the AA with Ukraine, Article 48 of the AA with Georgia and Article 174 of the AA with Moldova. The possibility of their conclusion, that has been called "industrial visa waiver" in the expert environment, is able to increase significantly the exports to the EU and reorient trade priorities from the agricultural sector, currently dominating in the export structure, to other product groups. At present, the Ukrainian party is stepping up efforts to sign respective treaty with the EU [15].

In addition to the directions of economic integration strengthening, experts also analyse possibilities of filling with the real content of the "political association" stipulated by the agreements [5].

At current, there are bilateral association bodies between the EU and the associated countries that include separate committees and clusters dealing mainly with the technical aspects of the Agreement implementation and have daily dialogue with certain units of the European Commission on specific issues. With the AA update, these institutions could gain more value. First, if they have mechanisms for prior informing and consulting on perspective legislation that is currently under development by the European Commission and will later need to be reflected in the updated annexes to the AA. A similar efficient mechanism for "supporting the uniformity of legislation" works in the EU - European Economic Area relations (Iceland, Liechtenstein and Norway) [Berezovska. 2011: 238-244]. Replication of such model within the framework of the association with the EaP countries, as I. Nahornyak fairly points out, could give the latter "the feeling of true partners to be reckoned with in Brussels" [14].

Obviously, the desire to review the AA and strengthen the EaP not supported with the largescale implementation of already existing contractual arrangements and working documents by the associated countries is unlikely to find rapid support from the EU. No wonder the doctrine says "The main weakness of this EaP strategy, however, is implementation" [Martinaitis. 2018:174] and states "there is a clear discrepancy between rule adoption and rule application".

We believe that the time remaining to deciding on the further evolution of the EaP can be used by the associated countries for the definite implementation of Priorities 20 for 2020 and demonstration of significant progress in the AA implementation.

Conclusions. The signing of the Association Agreements has become the highlight in the EaP policy evolution over the last 10 years. Today, there is a clear need for a fundamental update of this policy and definition of further priorities in the partnership development. Given the progress of Ukraine, Moldova and Georgia within the EaP, only a differentiated approach can give a new impetus to this initiative.

In the absence of better opportunities for enhancing integration that would open under the enlargement policy the associated countries should make the best of the potential EaP PLUS format's strengths.

Therefore, the period of consultations announced by the European Union is extremely important for upholding Ukraine's proposals for EaP PLUS and their implementation in a multilateral format of partnership. In this regard, the ability of Ukrainian diplomacy to convince 
Brussels becomes of particular importance for the fundamental update of the EaP. It is worth agreeing with $S$. Sydorenko's position that Ukrainian diplomacy has repeatedly demonstrated its ability to achieve what seemed to have little chance [15] and expressing the hope for success of the EaP evolution this time around.

To this end, the associated countries need to demonstrate, in the nearest future, a truly efficient work for the existing Association Agreements implementation and making use of opportunities to update them. Coordination of positions and joint actions of Ukraine, Moldova and Georgia is also important.

Under these conditions, the further evolution of the EaP could, despite the task complexity, contribute to enhancing the security in the region and the reality of the associates' intentions for EU membership.

\section{References}

1. Communication from the Commission to the European Parliament and the Council Eastern Partnership. Brussels, 3.12.2008 COM(2008) 823 final.

2. European Parliament recommendation of 15 November 2017 to the Council, the Commission and the EEAS on the Eastern Partnership, in the run-up to the November 2017 Summit (2017/2130(INI)).

3. Joint Staff Working Document Eastern Partnership - 20 Deliverables for 2020 Focusing on key priorities and tangible results Brussels, 9.6.2017 SWD (2017) 300 final. <https://eeas.europa.eu/sites/eeas/files/swd_2017_300_f1_joint_staff_working_paper_en_v5_p1_94 0530.pdf>

4. Закон України «Про Рішення Ради асоціації між Україною та СС про внесення змін і доповнень до Додатка XXVII до Угоди про асоціацію між Україною, з однієї сторони, та Європейським Союзом, Свропейським співтовариством з атомної енергії і їхніми державамичленами, з іншої сторони від 6 червня 2019 року№ 2739-VIII [Law of Ukraine “On the Decision of the Ukraine and EU Association Council amending Annex XXVII to the Association Agreement between Ukraine, of the one part, and the European Union, the European Atomic Energy Community and their Member States, of the other part, June 6, 2019, No. 2739-VIII] // Відомості Верховної Ради (ВВР), 2019, № 27, ст.112.

5. Emerson M. Scenarios for a Wider Europe. Centre for European Policy Studies, N 2019/02, February 2019 <https://www.ceps.eu/ceps-publications/scenarios-wider-europe/>

6. Loo G. The EU-Ukraine Association Agreement and Deep and Comprehensive Free Trade Area: A New Legal Instrument for EU Integration without Membership. - Leiden; Boston ]: Brill Nijhoff, 2016. Series: Studies in EU external relations ; volume 10, 434.

7. Solonenko I. 'Eastern Partnership Countries: democracy in limbo', EUobserver, 06.01.2015. <https://euobserver.com/opinion/127032; Eastern Partnership European Integration Index 2014, January 2015: www.eap- index.eu.>

8. Martinaitis Žilvinas. European Promises: Policy Options of Eastern Partnership Policy. Baltic Journal of European Studies Tallinn University of Technology (ISSN 2228-0588), Vol. 8, No. 2 (25), 164-181.

9. Артьомов I. Десятиліття Східного Партнерства: проблеми та перспективи [Тhе Decade of the Eastern Partnership: Challenges and Prospects]. Геополітичні пріоритети України. Збірник наукових праць. Випуск 1 (22), 2019, 7-29. <http://geopolitics-ofukraine.uzhnu.edu.ua/article/download/2078-1431.2019.1\%2822\%29.7-29/166198>

10. Березовська І. Правові механізми інтеграції в рамках Європейського економічного простору: досвід для України [Legal mechanisms of integration within the framework of the European economic space: more for Ukraine] // Право України. - 2011. - № 8. - С. 236-244.

11. Блокманс C. 10-річчя Східного партнерства: три поразки СС та шанс на оновлення. [10th Anniversary of the Eastern Partnership: three EU defeats and a chance for renewal]. $<$ https://www.eurointegration.com.ua/articles/2019/05/13/7096046/> 
12. Макаруха 3. 10-а річниия заснування інічіативи $Є C$ «Східне Партнерство»: нагода обговорити майбутнє партнерства після 2020 [10th Anniversary of the EU Eastern Partnership Initiative: an opportunity to discuss the future of the partnership after 2020]. Журнал європейського i порівняльного права, випуск 9 (2), 2018, $17-26$ < http://journals.iir.kiev.ua/index.php/pravo/article/download/3642/3310>

13. Мартинюк В. Більше безпеки та перспектива членства в СС: як варто змінити Східне партнерство [Better security and the prospect of EU membership: how the Eastern Partnership should be changed] <https://www.eurointegration.com.ua/articles/2019/07/3/7097905/> 14. Нагорняк I. Нова реальність для Східного партнерства: як зміниться ключова ініціатива $€ C$ [A new reality for the Eastern Partnership: how a key EU initiative will change] < https://www.eurointegration.com.ua/experts/2019/08/5/7099191/>

15. Сидоренко С. Свято без перспектив: що планує робити Євросоюз із форматом Східного партнерства [An official holiday with no prospects: what the EU plans to do with the Eastern Partnership format] <https://www.eurointegration.com.ua/articles/2019/05/15/7096156/>

16. Eastern Partnership structured consultation. An official website of the European Union <https://ec.europa.eu/neighbourhood-enlargement/tenders/consultation_eap_en>

17. Ukraine's Implementation of 20 Eastern PartnershipDeliverables for 2020Monitoring by the Ukrainian national platform of the EaP Civil Society PlatformState of Play as of 1 September 2018. <https://www.civic-synergy.org.ua/wp-content/uploads/2018/04/Ukraine-s-Implementationof-20-Eastern-Partnership-Deliverables-for-2020.pdf>

18. К Киів просить СС про нову стратегію відносин для України, Молдови та Грузї [Куіv asking the EU for a new relations strategy for Ukraine, Moldova and Georgia] <https://www.pravda.com.ua/news/2019/10/22/7229722/>

19. П Порівняльний аналіз «20 очікуваних досягнень Східного партнерства до 2020 р.» 3 положеннями Угоди про асоиіацію: якою є додана вартість для відносин Украӥна-СС? [Тhe Eastern Partnership's key deliverables compared with the Association Agreement provisions: what is the added value for the EU-Ukraine relations?].< https://www.civicsynergy.org.ua/en/analytics/the-eastern-partnership-s-key-deliverables-compared-with-theassociation-agreement-provisions-what-is-the-added-value-for-the-eu-ukraine-relations/> 20. "Промисловий безвіз»: оціночна місія СС може прибути вже у першій половині 2020 року [Industrial Dropping Off: EU Assessment Mission May Arrival in First Half of 2020] $<$ https://www.eurointegration.com.ua/news/2019/10/8/7101659/> 